Andreász Kosztopulosz - Éva Kuruczleki (eds.) (2020): The Challenges of Analyzing Social and Economic Processes in the 21st Century. University of Szeged Faculty of Economics and Business Administration, Szeged, https://doi.org/10.14232/casep21c.19

\title{
Motivations of brand avoidance
}

\author{
Dóra Tamasits
}

\begin{abstract}
Present study demonstrates the widely known and debated consumer-brand relationship, particularly focusing on the phenomenon of brand avoidance. However, the traditional consumer researches focus predominantly on the consumer loyalty, the examination of negative consumer-brand relationship is actual. The extant literature on the field brand avoidance is scarce. It is important to discover which factors are the those key elements that cause the brand avoidance. Firstly, if we know these factors we can prevent for more losing consumers. Secondly, nowadays the opinion of consumers is critic for the brand successful, because the negative word of mouth (WOM) might be harmful. Based on my previous suppositions the motivation of the brand avoidance are caused by symbolic consumption (selfexpression) which means consumers avoid certain brand because of the brand personality, brand image and the typical brand user. Partly, the results of the qualitative research certifies my previous suppositions, but the functional factors and the message of the advertisement are important elements for the brand avoidance as well.
\end{abstract}

Keywords: consumer-brand relationship, brand avoidance, anti-consumption

\section{Introduction}

A number of researches focus on the symbolic nature of brand loyalty, manifesting that consumers tend to insist on brands which they can express their personality with and which they can reach benefits through (Aaker 1997, Belk 1988, Levy 1959, Sirgy 1982). However, a few researches point out to the source of the motivations why consumers switch from one brand to the other one and why they avoid certain brands or products. It is also fundamental to reveal why individuals develop antipathy against a brand since if we know the reasons of brand avoidance it can be prevented to loose further consumers. Moreover, prevention and effective management of negative world-of-mouth might be essential for a successful brand. It is relevant to unravel experiences and motivations which are responsible for individual's negative attitude against the brand. After knowing this, solution could be found in order to shift the revulsion against the brand into a more favorable direction.

In a broader sense, current study aims to analyze the relationship between the consumer and the brand. Although it is researched both at theoretical and practical level nowadays, there is still a lack of clear framework of that. In the wide variety of different standardizations and methods, researchers and especially practitioners find it difficult to unravel those. It might be the reason why the consumer-brand relation is a less known approach both at theoretical and especially practical level in our country. In the narrow sense, the goal of current research is to examine the negative consumerbrand relation in depth which is less common in academic writings. Beside the academic overview, the study also contains exploratory research which aims to reveal 
the inducement of negative consumer-brand relation. The purpose of the primary research is to uncover the reasons which have an important role in negative consumerbrand relation, provided that consumer can afford to purchase a certain brand, it is available for the consumer but he deliberately chooses to avoid the brand and purchases one (or any) competitor of the certain brand.

\section{Anti-consumption as the theoretical background of brand avoidance}

A small variety of negative consumer-brand relation can be found among academic writings; therefore, this phenomenon is discussed within the field of anticonsumption. In case of negative consumer-brand relation, researches about anticonsumption are considered important which affect consumer's dissatisfaction, consumer's resistance and self-image (Lee et al. 2009a, Lee et al. 2009b, Iyer- Muncy 2009). In the researches of anti-consumption there is an attempt to reveal why consumers do not purchase certain brands or why they tend to decrease the purchase of a certain brand. In the field of anti-consumption one of the most important achievements is the standardization of anti-consumers that is connected to IyerMuncy (2009). The authors distinguished four different types according to the subject and purpose of their decreasing consumption. Based on that, chart No. 1 shows the consumer categories of anti-consumption.

Table 1 Four categories of anti-consumption

\begin{tabular}{cccc}
\hline & & \multicolumn{2}{c}{ Purpose of anti-consumption } \\
Societal Concerns & Personal Concerns \\
\hline $\begin{array}{c}\text { Object of anti- } \\
\text { consumption }\end{array}$ & $\begin{array}{c}\text { General (all } \\
\text { consumption) } \\
\text { Specific (individual } \\
\text { brand } \text { or products) }\end{array}$ & $\begin{array}{c}\text { Global impact } \\
\text { consumers } \\
\text { Market activists }\end{array}$ & Simplifiers \\
\hline
\end{tabular}

Source: Iyer-Muncy 2009 p. 161 self-edited

The table shows that there are consumers who tend to decrease or stop their consumption in general for all products, however, there are consumers who do this only for a few brands. Another important factor in distinguishing whether individuals consider social and environment issues (sustainability) or there is rather a personal motive of decreasing or stopping their consumption. One of the groups of anticonsumers is the group of activists protesting against global problems. In their point of view, the consumer society and the current level of the consumption have a negative effect on our environment. The over-consumption generates several problems and causes irretrievable damage in the ecosystem of the Earth. In order to draw attention to the negative effects of the over-consumption today and to how over-consumption influences our society and environment; an initiative was formed under the name „Buy Nothing Day” which can be considered as the opposite of Black Friday. The second group of the consumers against purchasing is „Simplifiers” (Holt 1998). They 
give up the lifestyle of the consumer society and choose a simpler, less consumptionoriented lifestyle. They think that the negative effect of the consumer society is the stress, fatigue and disillusion so the turn away from consumption-oriented lifestyle is based on an inner commitment. The activists of the market avoid a certain brand since according to them the brand or the company causes social problems. They are supported by several media in order to widespread the information regarding the negative effect. At last, the group of anti-loyal consumers intentionally do not purchase certain brands because in their opinion the brand is ,incompetent" or they have negative experience with the brand (Iyer-Muncy 2009). Based on the standardization of anti-consumers it is clear that the research of brand avoidance becomes multidimensional therefore it is worth to examine the phenomenon in a broader perspective. However, within this study the most relevant category is the group of the anti-loyal consumers since in my primary research I focused on the motivations of brand avoidance concerning one given brand.

\section{Motivations of brand avoidance}

There is no generally accepted definition of brand avoidance, there is usually an attempt to reveal behavioral patterns and motivations behind the phenomenon (Hogg 1998, Lee et al. 2009a, Lee et al. 2009b, White et al. 2012). The phenomenon of brand avoidance is formulated by Lee and the co-authors (2009b) when consumers deliberately refuse the purchase of a brand. The phenomenon suggests that consumer can financially afford to purchase the brand and it is physically available but he does not buy it. In an exploratory research Lee and the co-authors (2009a) classified the motivations in four main categories which may have a central role in brand avoidance. In furthers, Knittel el al. (2016) defined a fifth category also in an exploratory research. The motivations of brand avoidance are shown in figure Nr.1.

Figure 1 Motivations of brand avoidance

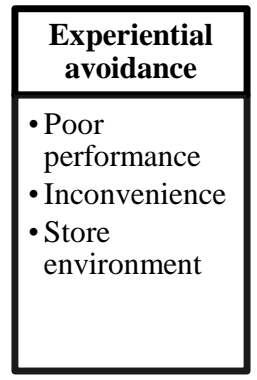

\begin{tabular}{|l|}
\hline \multicolumn{1}{|c|}{$\begin{array}{c}\text { Identity } \\
\text { avoidance }\end{array}$} \\
\hline - Negative \\
reference \\
group \\
- Inauthenticity \\
- Deindividuati \\
on \\
\hline
\end{tabular}
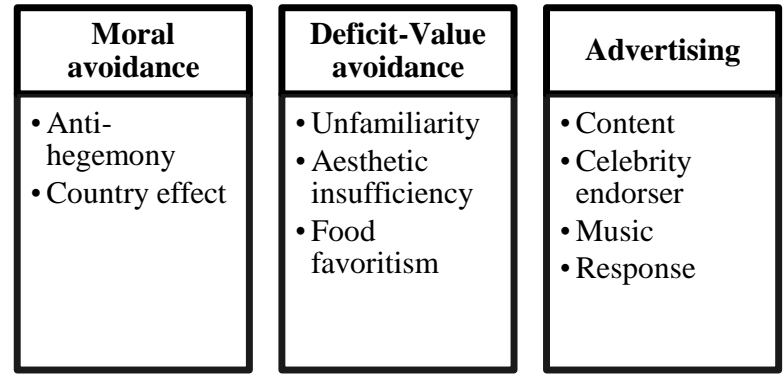

Sources: by Lee et al. (2009a); Lee et al. (2009b); Knittel et al. (2016); Nenycz-ThielRomaniuk (2011); White-Breazeale-Webster (2012) self- edited

Experiential avoidance means negative experience associated with the use and dissatisfaction of the brand. Experiential avoidance comes from the fact that promises of the brand do not match with the expectations of the consumer. He compares the 
expected and desired performance of the brand with the actual performance and if expectations do not match with the performance of the brand, it leads to dissatisfaction and brand avoidance (Lee et al. 2009a, Szántó 2003). Dissatisfaction includes the dissatisfaction associated with the performance of a certain brand and with the environment of the purchase itself.

Identity avoidance refers to factors which are associated with symbolic meanings of the brand and with the self-concept. The image of the brands mainly influence which brand is purchased by consumers since they can identify themselves based on the personality and symbolic meanings associated with the brand. The congruency of the individual's identity and the image suggested by the brand is called self-image congruence in academic writings (Sirgy 1982, Kressman et al. 2006, Grzeskowiak-Sirgy 2007, Gyulavári-Malota 2014). This is the phenomenon when the decision of consumer depends on how much the product image matches the selfconcept of the consumer. It was laid down by Grubb And Grathwohl (1967) that selfconcept has a value for the individual and his behavior, consumer's attitude is aimed at his defense and at the emphasizing the self-concept. The incongruence between the image suggested by the brand and the individual's identity leads to brand avoidance as there is a rejection of an undesired self-image behind the motivation of rejection. Identity brand avoidance includes the negative reference group, lack of authenticity and deindividuation. Negative reference group is a group where the consumer does not want to belong, that he refuses and whose values the consumer does not share (Lee et al. 2009b). The results of exploratory research of White-Breazeale-Webster (2012) show the difference from the classic brand user as the motivations of the brand avoidance. According to their views, brand avoidance is occurred partially in order to defense ,self", furthermore the aim is the preserve of the social self-concept where opinions of others might be dominant. Brand avoidance where the aim is to preserve social self-concept determined by White-Breazeale-Webster (2012) might be motivated by that consumers do not want to communicate towards other consumers that they belong to a lower social class by using a certain brand so they rather avoid them. In this case it is worth noting that there might be brands which are suitable to be used at home (where it cannot be seen by others), but they are not good enough to be seen that it is used. This perception of public feedback - the opinion or reaction of others - distinguishes consumers avoiding a certain brand in favor of their social selfconcept from those who avoid brand because of the defense of 'inner-self' (WhiteBreazeale-Webster 2012). Moreover, there are consumers who refuse certain brands in order to emphasize their personality since by consuming they do not intend to belong to those who follow the trends. They refuse certain brands since they prefer to be separated from the other consumers who follow the taste of the mass (Kovács 2009). Through this line of thought it is clearly seen that social interactions have an important role in researches of choosing brands and avoiding them.

In standardization of brand avoidance, the next category is the moral or ideological avoidance which can be based on the lack of corporate responsibility, country effects or power imbalance that is associated with imbalance between the power of a brand/company and the consumer (Lee et al. 2009a). 
The fourth category of brand avoidance is the deficit-value avoidance. Before consumer even could try a certain brand, he refuses it since the brand is perceived as bad because of the packing or because it is a new brand so the consumer is mistrustful. The quality that the consumer gets for a certain price, does not worth to him. Consumer goes through a pre-judgment whereby he decides not even to try it because it does not match his expectations. Deficit-value brand avoidance occurs when the price of the brand is not acceptable compared to the benefits deriving from the brand (Lee et al. 2009b). Consumers might avoid brand which reflect low quality therefore they have deficit-value (Lee et al. 2009b). Extending the four categories laid down by Lee et al. (2009b), Knittel (2016) and his co-authors revealed brand avoidance due to advertisements. In their researches they point out that brand avoidance can be triggered by less attractive content or advertisement message, celebrities in advertisements whom the consumer does not like, the music that evokes negative emotions in the consumer and the answers given to the advertisements which reflect to the subjective perception of the message recipient (Knittel 2016).

White-Breazeale-Webster (2012) have already highlighted the abovementioned motivations of brand avoidance. According to the three authors a brand can be active or passive trigger of phenomenon of brand avoidance. Brand is the active trigger of brand avoidance in case the consumers perceive ethnic or any other kind of discrimination or they think that the brand is responsible for social or economic problems. However, according to White-Breazeale-Webster (2012) the brand can also be the passive trigger of brand avoidance. Consumers usually associate the brand with a previous event from the past which the consumer has bad memories about. By refusing those brands which consumers have bad memories about, they try to avoid an undesired association. In this case individuals commonly have deep-rooted bad experience with the brand. It is worth to note that these negative experiences may be totally independent from the performance of the brand, for example a person who played a negative role in consumer's life, liked this brand (White-Breazeale-Webster 2012).

The above-mentioned conclusion shows that several reasons can lead to brand avoidance and these can be caused by social interactions, the subjective interpretation of the consumer or previous negative experiences. Memory also plays a central role since negative experiences may have a long-term effect in choosing a brand.

\section{Methodology}

The main goal of current research was to explore if the motivations of brand avoidance well known in the international academic writings can be also identified in domestic environment. I desired to reveal which behavioral and emotional manifestations alongside the negative relations to the brand can be defined. The topic of brand relationship is a highly emotion-driven field which requires a profound, exploratory research. So there is a reason why the experts of this field (Aaker 1997, Fournier 1998, Aggarwal 2004, Lee et al. 2009a, Lee et al. 2009b) also choose the qualitative methods. To reveal the motivations of brand avoidance I carried out the research in two steps. Firstly, I conducted the research as a two focus groups research, among a smaller but worldwide the mostly studied group (Rapp-Hill 2015) overall with 
participation of 15 university students. After that I prepared three in-depth interviews among people aged 28-38. The two different kinds of target groups were aimed to get a more complex picture of the motivations of brand avoidance. Both the in-depth interviews and focus group survey were carried out within half-structured frameworks so that participants could open up more. The methodology of the in-depth interviews and focus group survey slightly differ from each other. Due to the feature of both methodology I made some minor changes. During the focus group survey participants had to name one brand that they refuse, furthermore a product category and an emotion the brand makes him to feel. Within the in-depth interviews I asked the participant to list at least three, maximum five brands they could afford to purchase and it is available for them but they deliberately reject to purchase them. Moreover, if there are no other available products in that category in the store, they would buy rather nothing in that category if only that one product is available that they do not like. Participants of the in-depth interviews could freely choose three or five product or service brand. The only criteria were to choose only one brand from one product category. The goal of both the focus group survey and the in-depth interview as well was to reveal the attitude, experience and feelings of the individuals concerning the brand avoided. A screening questionnaire was also included in the interviews in order to avoid cases when there is a general rejection of the brand as the research of brand avoidance is not possible in this case. These were taken out from the analysis.

\section{Results}

In general, participants of both in-depth interviews as well as focus groups found it difficult to speak about the topic and the questions I have asked were considered too personal. Typically, clothing, smartphones, food, beverage, cosmetic articles and car brands were listed among rejected brands. In category of food there were cases when the product itself was rejected because of allergies so consumer does not purchase it or it does not fit into the lifestyle he tries to follow. In this case I ignored this brand in my research. In the followings, I will present the findings of my primary researches which makes it possible to reveal the motivations of brand avoidance of the participants. Result are summarized along the following 6 findings $(F)$.

Finding 1: Most of the participants have previous experience with the brand.

With one exception, participants mentioned brands which they had used, whether they purchased it or received it as gift. In this case the performance of the product researched in academic writings turns out as motivation of brand avoidance. The performance desired by participants did not match the real performance experienced. In some cases, their revulsion manifested in negative word-of-mouth.

'I used to buy and love this brand but now I cannot find any clothes for me. There are problems with the quality, style and size as well. I simply do not enter this shop.' (Viki) 'Yes, I got it as a gift but I would not buy clothes for me there.' (Adri) 'I was really disappointed with my last phone and since then I have been telling everybody not to buy it.' (Anna) 
It is also important to note that brand avoidance can also be triggered by indirect relation between individual and brand, in this case brand avoidance is not directly triggered by use of the brand.

'I was sitting in the car only as a passenger.' (Linda)

'I have not driven this type of car but I have already sat in such a type. It was not comfortable and I did not feel safe.' (Viki)

The above findings belong to the category of experiential avoidance well known from the academic writings since the reason of brand avoidance results from previous experience or actual use of the brand.

F2: Brand avoidance does not develop necessarily due to real consumer-brand interaction.

It is a key finding that antipathy against the brand can develop in the individual even before trying the product. This is due to the brand image evolved in the individual and to the image developed about the typical user of the brand.

'Personally, I have never had this type of dress but it has a really poor quality and it is expensive only because celebrities wear them. This really annoys me.' (Brigi)

'I have never used it and I do not intend to.' (Linda)

F3: The incongruence between individual's identity and the image suggested by the brand may trigger the brand avoidance.

Typically, the negative manifestation against the chosen brand derives from the fact that the suggested image of the brand is not attractive for people surveyed, in fact, the brand is repulsive for them and they do not intend to identify themselves with typical users of the brand.

'The product itself is good but I do not like it because of those who use it. '(Csaba) 'I do not want to became a user of mass products because people using this are boring, ordinary people of the middle-class.' (Linda)

'It is typical American; you meet it everywhere like a brainwashing mainstream. It is like they want to force it, moreover, if you do not have an iPhone, you may feel you are nobody. I do not want to belong to this medium.' (Adri)

Brand avoidance is also motivated by the desire to be separated from those following the trend. People surveyed do not intend to increase the mass by consuming that product.

'It is so fashionable and it is so much popular that everybody wants to purchase it. If there still were button mobile phones, I would definitely use that.' (Péter) 
It is an important observation that participants know people who buy the brand they are avoiding. In most cases people living in participant's immediate environment (family members, friends) are those who use the mentioned brand.

'The ones I know suffer from lack of confidence. They want to present something outwards, would like to stand out in the crowd, I look at them as buddies.' (Adri)

'Many people use it around me. They want to keep pace with the trends, they are interested in new things and do not want to miss anything new. I do not judge them.' (Viki)

'He is my sibling but he buys it because it tastes better. '(Linda)

F4: If the rejection of the brand is emotional then it is quite intense.

Moral avoidance appears intensively which can be associated with negative personal story as well. Participants described the issued brand as repulsive, repellent, anxious and frustrating.

'I was a child, you could mainly travel to the Easter European countries and you had to wait a lot at the borders where there were these cars. There remained a memory with me that you had to be afraid of border control because on the way there you were afraid what if they took the money you have with you. On the way back home we were afraid what if they took what we bought there. There were always Skoda's around us. I have an anxious feeling of Skoda which I would like to avoid.' (Linda)

'It is terrible, I hate it, it freezes, it keeps crashing, the battery drains fast-maybe just this model but everybody I know and uses this model hates the phone, it is impracticable.' (Viki)

In light of the above mentioned opinions it is to conclude that brand avoidance may have different levels which can be caused by dissatisfaction due to poor quality or a previous personal negative experience.

F5: Advertisements are significant in brand avoidance.

It was observed that participants were generally satisfied with the products but they do not purchase them due to the advertisements. However, it should be noted that in this case it is not totally an avoidance since if participants do not have a choice, they would purchase that brand. First of all, the mentioned brands were avoided by the interviewees due to their content and to the message they suggest.

'I would definitely not buy Pepsi. I do not like the advertisements, at most I would only chose it if there is no other option in a restaurant. It is lagging behind and does not see what is going on all around the world. It is trashy what Pepsi is doing in the world we live in. Advertisements should not approach from such a perspective; they should be more socially conscious. Pepsi does not perceive anything happening around them.' (Linda)

'It is pretty sneaky because they communicate how great it, how good that it is everywhere, whereas it is a trash. Advertisements do not suggest this and even children can afford to buy them' (Adri) 
F6: The purchase of the avoided brand may happen in the future.

The interviewees do not isolate themselves from the purchase of the given brand, except in case of some brands. However, it is noteworthy that they would not buy the product for personal use. For personal use they would purchase it only either if disincentive factors disappeared why they are currently avoid the brand or if they were forced in such a situation.

\section{'I would definitely not buy it for myself, maximum as a gift.' (Adri) \\ 'I would buy it under compulsion, if there is nothing else in the restaurant' (Linda) \\ 'Yes, if there is something in his size what he likes' (Viki)}

The above-mentioned findings are diverse in the view of the motivations of brand avoidance. According to the findings, the reason of brand avoidance is usually a previous negative experience with the use of the brand. At the same time, it is an essential finding that antipathy against the brand may evolve in the consumer even before testing the product. The reason of this is the brand image emerged in consumer's head and the image of the typical user of the brand. It also needs to be emphasized that results are strongly restricted by the size and content of the pattern so researches only show the opinions of those participating in the survey, these cannot be considered generally applicable.

\section{Conclusion, recommendation}

Despite the fact that the current research was carried out to a small group ( 2 focus groups with 15 university students, and 3 in-depth interviews between the ages of 28-38) are not suitable for generalizing the results, but the findings show well the relevance of researching brand avoidance. The motivations revealed in the qualitative research are in accordance with those demonstrated in academic writings. From the types of the motivations for brand avoidance, identity avoidance and experiential avoidance were the most significant ones in my research while brand avoidance caused by advertisements is less remarkable. It is important to highlight that based on the findings participants do not close themselves off to purchase of the mentioned brands, however, they would not buy them for personal use or just in case if disincentive factors disappeared why they do not purchase them. Brand avoidance mostly results from a previous negative experience which may be related rather to the use of the brand than to some negative experience. Emotions were less outstanding in connection with a brand avoided, but in case they appeared those were extremely intense.

The practical use of researching brand avoidance is particularly relevant for brand management. If consumers consider a brand negative, it is worth to focus on another field from marketing aspect. Experiential brand avoidance can be effectively addressed with developing a proper complaint handling or repositioning the brand may be also a possible solution. Moreover, negative attitude to the brand can be changed positively if the brand or the company takes actions for corporate social responsibility and this has a press coverage. However, in case of experiential brand avoidance, improving the product quality might be advisable for companies. 


\section{Summary}

Understanding how consumers perceive the benefits of the brands, how they interpret the message of the brand and the brand personality contributes to the development and function of consumer-brand relation. The goal of current research was to point out to the motivations of negative consumer-brand relation and I aimed at revealing those motivations which are significant in brand avoidance. Findings show that brand avoidance has diverse, subjective reasons and it was outlined that brand avoidance may appear in different levels. Table 2 displays these findigs.

Table 2 Findings

\begin{tabular}{|c|c|}
\hline Findings & Explanations \\
\hline $\begin{array}{l}\text { 1. Most of the participants have } \\
\text { previous experience with the brand. }\end{array}$ & $\begin{array}{l}\text { Participants mentioned brands which they } \\
\text { had used, whether they purchased it or } \\
\text { received it as gift. }\end{array}$ \\
\hline $\begin{array}{l}\text { 2. Brand avoidance does not develop } \\
\text { necessarily due to real consumer- } \\
\text { brand interaction. }\end{array}$ & $\begin{array}{l}\text { Antipathy against the brand can develop } \\
\text { in the individual even before trying the } \\
\text { product. }\end{array}$ \\
\hline $\begin{array}{l}\text { 3. The incongruence between } \\
\text { individual's identity and the image } \\
\text { suggested by the brand may trigger } \\
\text { the brand avoidance. }\end{array}$ & $\begin{array}{l}\text { The negative manifestation against the } \\
\text { chosen brand derives from the fact that } \\
\text { the suggested image of the brand is not } \\
\text { attractive for people surveyed. }\end{array}$ \\
\hline $\begin{array}{l}\text { 4. If the rejection of the brand is } \\
\text { emotional then it is quite intense. }\end{array}$ & $\begin{array}{l}\text { Brand avoidance appears intensively } \\
\text { which can be associated with negative } \\
\text { personal story as well. }\end{array}$ \\
\hline $\begin{array}{l}\text { 5. Advertisements are significant in } \\
\text { brand avoidance. }\end{array}$ & $\begin{array}{l}\text { The mentioned brands were avoided by } \\
\text { the interviewees due to their content and } \\
\text { to the message they suggest. }\end{array}$ \\
\hline $\begin{array}{l}\text { 6. The purchase of the avoided brand } \\
\text { may happen in the future. }\end{array}$ & $\begin{array}{l}\text { The interviewees do not isolate themselves } \\
\text { from the purchase of the given brand, } \\
\text { except in case of some brands. }\end{array}$ \\
\hline
\end{tabular}

Source: self-edited based on my qualitatitve research

Negative emotions and bad experience with the brand might be relevant in the brand avoidance therefore it is worthwhile to reveal what kind of roles these factors have in developing and continuing negative attitude towards the brand. The finding that participants would purchase the avoided brand in most cases - even if not for personal use - raises further questions. Future researches may focus on cases whether an influencer can persuade the consumer to buy the brand which is avoided due to some reasons. Moreover, based on the dynamic of consumer-brand relation, it may be an exciting research field, towards which brands consumer change their opinion and due to what. Another point is strongly related to this, specifically if there is a brand in consumer's life which they previously claimed not to purchase but later on they did. Current research examined the brand avoidance in a qualitative way, however, it would be worth carrying out quantitative researches in this field. 


\section{References}

Aaker, J. L. (1997): Dimension of brand personality. Journal of Marketing Research, 34, 347-356.

Aggarwal, P. (2004): The Effects of Brand Relationship Norma on Consumer Attitudes and Behavior. Journal of Consumer Research, 31- June 87-101.

Belk, R.W. (1988): Possessions and the Extended Self. Journal of Consumer Research,15- September 139-168.

Fournier, S. (1998): Consumers and Their Brands: Developing Relationship Theory in Consumer Research. Journal of Consumer Research, 24, 343-372.

Grzeskowiak, S. - Sirgy, J.M. (2007): Consumer Well-Being (CWB): The Effects of Self-Image Congruence, Brand Community Belongingness, Brand Loyalty, and Consumption Recency. Applied Research Quality Life, 2, 4, 289-304.

Grubb, E.L. - Grathwohl, H. L. (1967): Consumer Self-Concept, Symbolism and Market Behavior: A Theoretical Approach. Journal of Marketing. 31- October 22-27.

Gyulavári T. - Malota E. (2014): Az énkép-illeszkedés elmélet szerepe a fogyasztók turisztikai desztinációértékelésében. Marketing \& Management, 48, 3, 5-14.

Hogg, M. K. (1998). Anti-Constellations: Exploring the Impact of Negation on Consumption. Journal of Marketing Management, 14, 133-158.

Holt, D. B. (1998): Does Cultural Capital Structure American Consumption? Journal of Consumer Research, 25, 1, 1-25.

Iyer R. - James A. - Muncy J. A. (2009): Purpose and object of anti-consumption. Journal of Business Research, 62 160-168.

Kovács K. (2009): A divatterjedés és a divattermékek fogyasztását befolyásoló tényezők empirikus vizsgálata a hazai fiatalok körében. Marketing\&Menedzsment. 43 (1) 62-71.

Knittel, Z. - Beurer, K. - Berndt, A. (2016): Brand avoidance among Generation Y consumers. Qualitative Market Research: An International Journal, 19, 1, 27-43.

Kressman, F. - Sirgy, M.J. - Herrmann, A. - Huber, F. - Huber, S. - Lee, D.J (2006): Direct and indirect effects of self-image congruence on brand loyalty. Journal of Business Research, 59, 8, 955-964.

Lee, M. S.W. - Conroy, D. - Motion, J. (2009a): Brand Avoidance: a Negative Promises Perspective, Advances in Consumer Research, 36, eds. Ann L. McGill and Sharon Shavitt, Duluth, MN: Association for Consumer Research, 421-429.

Lee, M. S.W. - Motion, J. - Conroy, D. (2009b): Anti-consumption and brand avoidance. Journal of Business Research, 62, 169-180.

Levy, S. J. (1959): Symbols for sale. Harvard Business Review, 37, 4, 117-124.

Nenycz - Thiel, M.- Romaniuk, J. (2011): The Nature and Incidence of Private Label Rejection. Australasian Marketing Journal, 19, 93-99.

Rapp, J. M. - Hill, R.P. (2015): Lordy, Lordy, Look Who's 40! The Journal of Consumer Research Reaches a Milestone. Journal of Consumer Research, 42, $1,19-29$. 
Sirgy, M. J. (1982): Self-concept in consumer behavior: A critical review. Journal of consumer research, 9, 287-301.

Szántó, Sz. (2003): Cikkek a fogyasztói magatartás témaköréböl. BGF-KKFK, Nemzetközi Marketing Tanszék, Budapest.

White, A.- Breazeale, M.- Webster, C. (2012): Motivations for the brand avoidance relationship. In Fournier, S. - Breazeale, M. - Fetscherin, M. (ed.): ConsumerBrand Relationships Theory and Practice. Routledge, London and New York, 57-73. 